\title{
Health stressors, problems and coping strategies of migrant domestic workers: A scoping review
}

\section{Ken Hok Man HO ( $\nabla$ hhm312@yahoo.com.hk)}

The Chinese University of Hong Kong Faculty of Medicine https://orcid.org/0000-0003-4934-2450

Ingrid M Wilson

Singapore Institute of Technology

Janet YH Wong

The University of Hong Kong Li Ka Shing Faculty of Medicine

\section{Lisa McKenna}

La Trobe University School of Nursing and Midwifery

\section{Sonia Reisenhofer}

La Trobe University College of Science Health and Engineering

\section{Ferry Efendi}

Universitas Airlangga

Graeme D Smith

Caritas Institute of Higher Education

\section{Research Article}

Keywords: coping, migrant domestic workers, health, stressors, scoping review

Posted Date: July 15th, 2021

DOl: https://doi.org/10.21203/rs.3.rs-648961/v1

License: (c) (1) This work is licensed under a Creative Commons Attribution 4.0 International License.

Read Full License 


\section{Abstract}

Migrant domestic workers have become a major international target population for issues of human rights. However, little is known about the stressors, problems, and coping strategies surrounding their health issues internationally. A scoping review identified 26 sources matching selection criteria through a systematic search on 10 databases with publications from January 1995 to December 2019. Analysis revealed that stressors to health included abuse, poor health services accessibility, ongoing financial hardship despite demanding working conditions and social isolation. Several physical and mental health problems were identified for which migrant domestic workers largely depended on social network and religion to cope with stressors and health problems. Marginalization in health and social care system was evidenced in various countries that formal health and social care for migrant domestic workers was lacking. Survey on health problems of migrant domestic workers and provision of formal support to them present a significant service gap.

\section{Introduction}

Since Hoschschild introduced the concept of the global care chain as "a series of personal links between people across globe based on the paid or unpaid work of caring" (1), migrant domestic workers (MDWs) have become a major international target population for issues of human rights. MDW can be defined as a full-time worker who is tied to an employer either through a regulated work permit or underground contract that allows him / her to work for a single household $(2,3)$. The global care chain initially captured the phenomenon of women migrating from global south to care for children in households of employed women in the global north, whilst those women migrant workers left their own care work in their country of origin (4). Furthermore, the trend of global population ageing created a new wave of the global care chain in which women from less wealthy countries moved across borders to take up domestic care for older adults in more wealthy households (5). There is an estimated 11.5 million MDWs in the world, of which $75 \%$ are female (6). The phenomenon of MDWs has raised issues surrounding the rights of (female) migrant laborers and uncovered inequalities on genders, economic classes, ethnic groups and legal status imposed on migrants driven by the global care chain $(7,8)$. To date, support for MDWs' health-related issues has received little attention around the world $(3,9)$. Presently, little is known about issues surrounding the health experiences of this migrant workforce.

The traditional work of MDWs has generally been characterized as the three Cs: cooking, cleaning and caring (10). Migrants have played a significant role in meeting the escalating demand for social care, particularly home care, in the UK (11). People from Poland have been employed as domestic workers in Germany to take care of older adults (8). In Scandinavia, Sweden provides tax reductions for older adults to pay for "top up" care services from migrant workers (7). Filipina domestic workers have been employed to care for older adults in Cyprus (12), Southern California (13) and Israel (14). The demand for MDWs for long term care of older adults is also extensive across Asian countries. Approximately $14 \%(n=183,000)$ Hong Kong older adults are being cared for by MDWs (15). The number of MDWs hired to specifically care for older adults was projected to increase from 198,000 in 2011 to 300,000 by 2030 (16). Currently, 
$12.8 \%$ of frail older adults in Taiwan are under the care of migrant domestic workers(17) and $17.4 \%$ of Israeli older adults received government subsidies to hire MDWs (18).

Alongside the increasing popularity of MDWs worldwide, violations of their human and labor rights have been identified, with ensuing health implications. MDWs are known to have excessively long working hours without compensation and with limited organizational support $(5,11)$. For instance, $11 \%$ of MDWs in Hong Kong have reportedly been deprived of their weekly days off, affecting their health and wellbeing (15). Discrimination based on skin color, language and ethnicity have been dominant themes in studies of MDWs $(19,20)$. Being entrapped in a household, MDWs lack structural organizational support when faced with exploitation (21). The role of MDWs has a unique nature, as both employee and caregiver of their employer, requiring MDWs to employ heavy emotional labour in their relationships with care recipients (22). As such, mental health of MDWs is a major issue (23). In actuality, half of MDWs in China reportedly found it difficult to manage negative emotions (24). When the employer-employee power relationship intersects with a lack of social and organizational support, MDWs were highly vulnerable to abuses by employers (21). In fact, abusive behaviors by employers, such as physical and verbal abuse, sexual harassment, and economic exploitation were identified as common stressors that trigger negative emotions among MDWs $(25,24)$. Due to their live-in working arrangements, MDWs provide around the clock care to recipients, potentially having an impact on their physical health status. For example, $52 \%$ of MDWs complained of lack of sleep and $73 \%$ reported not having regular mealtimes, due to the constant demands of their caregiving work (15). In recent years, attention to the health of MDWs has mainly focused on issues of sexual health, particularly HIV (26). There is a lack of systematic information on the broader stressors and health problems affecting MDWs worldwide.

From a human rights perspective, identifying stressors and subsequent coping strategies used by MDWs to address their health problems is merited. Human rights issues are meant in the first instance to guide the actions of governments and have implications for health policy and practice $(27,28)$. However, around the world MDWs have limited access to health and social protection $(21,5)$. Due to social, cultural and physical isolation, MDWs often face the problem of accessing and utilizing health-related information (3). It has also been highlighted that healthcare professionals (e.g. nurses) and current healthcare services and policies were unable to meet the needs of MDWs $(29,3)$. Failure to protect and promote the health of MDWs may indirectly have a negative impact on the wellbeing of their care-recipients, as well as the global economy. For example, the cost of informal care of older adults with dementia accounts for $0.44 \%$ of global GDP in 2015, whilst that of direct medical and social care for older adults with dementia was $0.65 \%$ of global GDP (30). The increasing trend of hiring MDWs to provide long-term care for older adults has the potential to further increase the sharing of informal care, aligned with the global trend of ageing in place. Meanwhile, it is well acknowledged that promotion of the health and wellbeing of informal caregivers is crucial for the health and wellbeing of the care recipient $(31,32)$. As such, this scoping review aimed to systematically explore and review the wide range of health and wellbeing issues surrounding MDWs, in order to identity and synthesize stressors impacting their health, their health problems and coping strategies they employed, to inform health and social care practice and policy. 


\section{Methods}

We employed Arksey and O'Malley's (33) five stage framework and followed the advice of Levac and colleagues (34) to synthesize and analyze a wide range of literature. Arksey and O'Malley (33) proposed five stages to conduct a scoping review: (1) identifying the research question; (2) identifying relevant studies; (3) selecting studies; (4) charting the data; and (5) collating, summarizing, and reporting the results. Underpinned by the framework (33), this study is reported according to the 22-item Scoping Review Checklist (35). Steps one to five of this five-stage framework (33) are described below.

\section{Identifying the research question}

The research questions addressed by this review were:

1. What is known about the stressors impacting health of MDWs?

2. What are the health problems faced by MDWs?

3. What are the coping strategies employed by MDWs in response to the stressors and health problems?

\section{Identifying relevant studies}

Relevant studies were identified principally by systematic searching electronic databases including Scopus, Web of Science, CINAHL, Medline, PsychInfo, Proquest, PubMed, Garuda (Indonesian Publication Database), Business Source Complete, and China Journals Full-text Database with the publications from January 1995 to December 2019. Various combinations of the medical subject headings (MeSH) with Boolean operators AND and OR were used: "domestic helper", "domestic worker", "migrant worker", foreign worker", domestic employee", "health", "well-being", "psych*”, "mental”, "emotional”, "physical”, "work life". A second search was also conducted by reviewing the list of bibliographic references of the relevant and included studies. Due to the cultural diversity in the team, we were able to extend our search to literature in English, Chinese and Indonesian languages.

\section{Selecting studies}

The review was conducted in accordance with PRISMA reporting (36). In total, 2,377 references were obtained for literatures in English, Chinese or Indonesian, of which 1,511 were eliminated as duplicates. A study team of seven members screened the titles and abstracts of the remaining 866 articles using the Covidence software platform (37). Each articles was screened independently by two team members with disputes resolved by a third team member. After reviewing titles and abstracts, 82 full-text relevant articles were retrieved and screened again. Articles were screened based on the following inclusion criteria: (1) only international peer-reviewed studies and original articles; and (2) research design was quantitative, qualitative, or mixed methods studies. Studies were excluded that (i) only mentioned about social construction of exploitation or abuses on MDWs, or (ii) participants who were migrant workers but not engaged in domestic work. We also excluded commentaries, discussion papers, editorials, literature 
reviews and book chapters. Monthly meetings were carried out to clarify the study selection eligibility criteria. After a consensus meeting, studies not focused on the health and wellbeing of domestic migrant workers were also excluded. No Chinese or Indonesian literature met the inclusion criteria. In total, 25 articles were included, and an additional study was retrieved from a reference list of an included article. Therefore, 26 articles were included in the final scoping review. The search process is provided in Fig. 1.

Figure 1 insert here.

\section{Charting the data}

Using Microsoft Excel, characteristics of included studies (Table 1) were initially developed to extract data on author, year, study design, research objectives, number of participants, study location, and worker country of origin. In accordance with the inductive nature of scoping review (33), no studies were excluded on the basis of quality. Another table (Table 2) was further developed to extract specific data on stressors on health, health problems and coping strategies. All data charting was conducted independently by two reviewers and results were cross-checked by other team members.

Table 1 and Table 2 insert here.

\section{Collating, Summarizing, and report results}

In accordance with the guidance provided by Levac et al. (34), we developed a descriptive summary to collate and summarize the results. The analysis presents a narrative description and synthesis of the existing literature using the research questions as a conceptual framework. Studies were coded and categorized according to their relevance to the research questions. Coding and categories were then synthesized into themes for presentation (38).

\section{Results}

The 26 included studies encompassed qualitative studies $(n=8)$, quantitative studies $(n=13)$ and mixed methods studies $(n=5)$. Eighteen studies focused specifically on workers from the Philippines $(n=13)$, Indonesia $(n=2)$, Ethiopia $(n=2)$, Nepal $(n=1)$, Burma $(n=1)$ and Russia $(n=1)$. Other studies included a mixture of participants from Philippines, Indonesia, Colombia, Morocco, Senegal, Romania, Sir Lanka, Burma, Vietnam, Sri Lanka, India and Bangladesh.

\section{Stressors impacting health}

Four categories of psychosocial issue, namely: (i) work-related abuse and exploitation, (ii) poor literacy and accessibility to health services and health insurance, (iii) inescapable financial hardship despite demanding working environment, and (iv) social isolation, were identified as dominant stressors influencing the health of MDWs.

\section{Work-related abuse and exploitation}


Work-related abuses were typically described in categories of sexual abuse, physical abuse, emotional abuse (including verbal abuse) and exploitation, with varying prevalence across countries or cities. The prevalence of abuses experienced by MDWs in Israel was particularly disturbing: sexual abuse (8.2\%), physical abuse (5.9\%), emotional abuse (38.8\%) and exploitation (64.7\%) (39). Their latter study (40) further showed that MDWs (7.4\%) were more vulnerable than local care workers (2.5\%) to work-related abuses. Another survey of Nepalese female MDWs in the Middle East and Malaysia showed that $40.9 \%$ suffered abuses in the workplace, including reports of physical harm $(11.1 \%)$ and torture or maltreatment (30.8\%) (41). In Hong Kong, 20.5\% and 34.4\% of MDWs experienced physical and verbal abuses respectively (29). One noteworthy case in Thailand revealed that a male MDW suffered sexual abuses by a male employer repeatedly without reporting to officials or friends (42), amidst the feminization of global care chain. Meanwhile, Green and Ayalon (2018) (40) found that MDWs' worker rights were violated in the following ways: (i) did not receive vacation days (58.4\%), did not receive paid sick days (76.1\%), did not receive written contracts (15.8\%), did not receive the financial compensation they were entitled to (39\%), and did not receive weekly days off (35\%). From North America, Canadian studies suggested that the household, as a private workplace, presented significant difficulties for officials to enforce existing labor laws, leaving MDWs highly vulnerable to abuses and exploitation with sense of powerlessness $(43,44)$.

\section{Poor literacy and accessibility to health services and health insurance}

Accessibility to health services and health insurance created difficulties for MDWs across both developing and developed countries - specifically health illiteracy was identified as a contributing factor. The unmet need for health services (18\%), unmet need for pharmaceuticals $(10 \%)$ and high levels of health illiteracy $(73.8 \%)$ were reported in one Cyprus quantitative study (45). Toyota (42) commented on the impact of health illiteracy in MDW in Thailand, where poor AIDS knowledge left MDWs with extremely restricted options for their own health and wellbeing. Simkhada et al (41) revealed that only $12.9 \%$ of Nepalese MDWs received workplace health services in the Middle East and Malaysia and illiteracy was significantly associated with their health problems $(p<0.001)$. In Canada, accessibility to health services for MDWs was dependent upon compulsory insurance coverage provided by employers (46). However, there were cases where MDWs lacked awareness about the legal requirement for employers to provide insurance coverage, resulting in no insurance coverage for health services during their first three months of employment (46). Systemic inequity, in which MDWs were structurally excluded from healthcare system of host countries, was found to be a dominant contributor to their poor accessibility in both developed (e.g. Canada) and developing countries (e.g. Lebanon) $(47,44)$.

\section{Inescapable financial hardship despite demanding working environment}

One Singaporean qualitative study revealed that overcoming poverty motivated migrants to join the domestic care workforce in the host countries (48). This was confirmed in a Filipino study where financial $(52.8 \%)$ and income (43.9\%) concerns were dominant among MDWs (49). However, domestic work is 
highly demanding, the daily hours of work ranges from 12 to 18 hours $(43,41,50)$. The domestic work was even more demanding if older adults were the care recipients. The daily hours of work increased to 20 hours for MDWs caring for older adults in Singapore (51). Particularly, caring for older adults costed an emotional toll on MDWs $(52,52)$. The highly demanding domestic work is detrimental to the wellbeing of MDWs and does not bring a permanent solution to MDWs' financial problems because the hardship returns upon termination of employment (49). This is best explicated by a participant's quote "I am so stressed and actually I was on sick leave for 12 days because of the stress but what I keep worrying is about my family, that if I lose my job right now, because I know I'm not happy with it... If I leave this job and I cannot find a job tomorrow then I lose pay" (44). As such, quitting domestic work is not an option for MDWs, despite enduring (53).

\section{Social Isolation}

Social isolation was identified as a major issue related to domestic work in various qualitative studies $(52,53,46,51,42,44)$. Around $48 \%$ of MDWs suffered mild to severe level of social isolation in Singapore (54). Employers were found to play a major role in constructing the social isolation of MDWs in various ways from forbidding MDWs to connect with the outside world through telephone, to more extreme measures such as fencing them within the home (42). Meanwhile, the long working hours of domestic care and lack of alternative co-workers contributed to workplace isolation, in which MDWs carried out their work with no-one to talk to or interact with $(52,51)$. Another reported source of social isolation was being separated from family (46), reinforcing their sense of otherness in host countries (53).

\section{Physical and mental health problems}

The phenomenon of the "healthy immigrant effect" was identified generally across studies in both Eastern and Western countries $(53,44)$. The healthy immigrant effect refers to progressive health declines experienced by MDWs in host countries, after arriving in their host countries with excellent health (48). In a Canadian study, MDWs commented that the nature of domestic work (e.g., the live-in arrangement, demanding work) created new physical and mental health problems that were absent before migration (46).

\section{Physical health}

Various types of physical problems were mentioned across a number of qualitative studies, including cardiovascular diseases (e.g. hypertension) $(46,55,47,44)$, respiratory diseases (e.g. tuberculosis) (47), chronic pain $(47,55)$, diabetes $(55,44)$, poor sleep $(52,46)$, and fatigue $(52,43)$. Survey data on the above physical problems were absent in the literature that we retrieved. While these physical issues might be attributed to the stressors discussed above (e.g., long working hours) (46), some stressors (e.g., poor sleep and fatigue) were also signs and symptoms of somatization of mental issues $(52,56)$. A study in Hong Kong investigated the oral health status of MDWs in which psychosocial determinants explained $13.2 \%$ of variance of caries severity (57). Reproductive and sexual health was also a major concern for MDWs (42). In a study of 1,001 MDWs in Malaysia and the Middle East, $3.1 \%$ had fallen pregnant in the 
course of their employment; $50 \%$ of these cases $(n=16)$ was the result of rape/sexual abuse, while the remainder of pregnant women had consensual sexual relationships. Such pregnancies created additional problems for MDWs as sexual relations is forbidden in these Muslim countries (41). With poor accessibility to health services, there were cases in Lebanon that pregnant MDWs were denied admission to hospital and were forced to deliver at home (47).

\section{Mental health}

Feeling stressed is commonly found in MDWs in various studies $(54,58,46,43,59)$. In Singapore, $52.5 \%$ of MDWs reported feeling stress (54). A survey in the Middle East and Malaysia showed that $8.8 \%$ of MDWs had mental health problems, although the diseases were not specified (41). Anxiety and depression were frequently mentioned by MDWs in qualitative studies $(52,46,55,44)$. The prevalence of anxiety among MDWs was $17.6 \%$ in Macao, China (60). 10.3-18.2\% of MDWs suffered moderate to severe level of depression across various countries $(58,29,60,50)$. Two studies in Macao and China showed that postmigration stress was associated with increased anxiety, depression, somatization and post-traumatic stress disorders $(61,56)$. The mental health issues, coupled with poor social support, contributed to additive gambling behavior of MDWs in Macao, China $(55,62)$. Loneliness and homesickness were mentioned in MDWs' narratives (53) with a prevalence of $24.8 \%$ in a Filipino study (49). It is noteworthy that $66.7 \%$ of MDWs were diagnosed with brief psychotic episodes in Lebanon (50).

\section{Coping strategies}

Most commonly reported strategies to cope with stress and to foster resilience were: (i) establishing social networks, and (ii) participating in religious activities. No health or social care interventions have been identified to assist MDWs to cope with their health problems.

\section{Establishing social networks}

For Ethiopian MDWs, establishing social networks and contact with peers served the function of sharing information and advice, to engage in religious worship together and comfort themselves just by seeing each other (53). Those MDWs with higher levels of social connection expressed higher levels of quality of life in Singapore (54). Conversely, social network is not always been seen to be beneficial. For MDWs in Macao, China, social support from peers was positively associated with psychological distresses $(60,56)$, mainly as peers shared the same problems and were similarly stressed (55). Some MDWs in Singapore indicated that social support was not helpful (48). Meanwhile, employers were identified as a prominent and first line source of support (inclusive instrumental, emotional and financial) for MDWs in various studies $(51,45,49)$. However, less than $50 \%$ of MDWs reported abuse by employers, either formally to officials or informally to friends and family (39). Motivating them to persevere, MDWs also tried to maintain regular contact with their family members through messages, phone calls and video calls (51). In some settings, there were cases where social contact with friends and family was prohibited by employers of MDWs (53). This scoping review did not found any organizational support provided for MDWs. 


\section{Participating in religious activities}

Religion was a very important aspect for many MDWs and religious activities performed included singing, prayer, going to church and reading religious texts (48). In the Philippines, praying / reading the Bible (55.2\%) was a major strategy for MDWs to cope with stress (49), although the stress levels between those who prayed/read the Bible and those who did not showed no differences (63).

\section{Discussion}

To our knowledge, this is the first scoping review and synthesis of literature related to the health status of MDWs involving 16 countries or cities globally. As such, it indicates MDWs' health is a global issue and provides a valuable addition to the existing literature, bringing to light the health-related experiences of MDWs. Whilst research on the health of MDWs may be limited, it appears to have grown significantly in recent years. Over half of the resources used in this scoping review date from 2016 onwards. In general, the working conditions of MDWs may vary but similar problems have been identified across reporting countries. As live-in employees, MDWs have consistently been found to have problems of long working hours, social isolation and abuse. As informal caregivers, the factors that account for the highest levels of distress in family caregivers also appear to apply to MDWs, including the fact that the majority are female, with low levels of education, live with their care recipient, spend a vast amount of their time caregiving and have no choice about providing such care (64).

The unique employment relationship of MDWs with their employers increases their vulnerability to physical and mental abuse (65). Not surprisingly, studies in this review highlighted issues of abuse and exploitation of MDWs. Globally, MDWs continue to be at significant risk of physical, psychological and sexual abuse in their employment (29). According to our findings, the prevalence of abuses and exploitation ranged from 5.9-64.7\%, depending on the types of abuses and the countries. However, the prevalence of abuse and exploitation may be underestimated because of under-reporting with MDW's fearful of repercussions from their employers, such as losing their job (66). This is indicated by our findings that less than $50 \%$ of MDWs reported abuses by employers either formally to officials or informally to friends or relatives. Paradoxically, MDWs also identified employers as a major source of social support $(51,45,49)$. For example, a Cypriot study noted that the role of the employers was very important, not only in relation to MDW's access to health services, but also to the quality of care they received (67). As such, our findings agreed with Bauer and Österle (68) that MDWs are dependent on their employers for various aspects, both materially, such as income, and emotionally. This highlighted their vulnerability due to an unequal power relationship (66). Despite difficulties enforcing labour law in private home settings (12), our scoping review did not identify any structured social support for MDWs to mitigate their dependency on employers. Urgent attention should be given to the development of a comprehensive approach to abuse reporting.

Our findings of poor accessibility to health services are supported by those of Weng et al (69), highlighting that time flexibility and language barriers were the main obstacles to accessing health 
services for Indonesian MDWs in Taiwan. The vast majority of MDWs have their weekly time off at the weekend, hampering access to routine health services which are generally provided during working days (70). MDWs in Taiwan were even provided with only one day off each month (71). Furthermore, MDWs generally have limited health literacy in their host countries, mainly because of numerous socio-cultural disadvantages, impacting their ability to access and understand health-related information and services (3). According to our findings, MDWs mainly shared information and advice by establishing social networks and contacts with fellow workers (53). However, social networking with fellow workers was not always entirely positive. Peers also shared the similar problems (55). To improve the health literacy of MDWs, Ho and Smith(3) advocated the delivery of health literacy initiatives through a participatory approach working with community stakeholders (e.g., consulate and community nurses).

The 'healthy immigrant effect' was identified as a problematic phenomenon for MDWs in relation to declines in physical health and mental health (23). This scoping review uncovered a research gap that systematic survey data on physical problems, inclusive sexual and reproductive health, faced by MDWs is lacking, despite a vast number of qualitative studies indicating the onset of illnesses after migration. We believe the first step to alleviate the systemic inequality for MDWs to access health services and health insurance is to assess the health needs of MDWs accurately, uncovering the scope of health problems faced.

Furthermore, high levels of stress, anxiety and depressive symptoms were common in MDWs across all geographical regions. One systematic review identified that common stressors which triggered emotional and psychological problems in MDWs included, abusive behavior by employers, sexual harassment, economic exploitation, demanding working environment and recurrent financial hardships (24), all consistent with the findings of our review. In particular, this scoping review identified a range of physical problems, such as chronic pain, fatigue, sleeping difficulties, gambling behavior and suicide, indicating the potential of somatization of mental problems faced by MDWs. However, none of the included studies indicated the availability of any formal supports provided to MDWs with mental problems and its somatization, identifying a significant service gap.

Our findings of social support and participating in religious activities shed light on the importance of resilience for MDWs to protect them against the identified stressors and health problems. Paradoxically, our review also uncovered the fact that MDWs largely depended on internal resources (e.g., religious beliefs) to cope with adversities, while social networks from employer and fellow were not always effective. The World Health Organization highlights the importance of building environments to strengthen resilience (72). However, our review was unable to locate any structural support offered to MDWs. In contrast, our review showed that MDWs were structurally excluded from health and social services $(47,44)$, hampering their resilience. In accordance with Walsh and Shutes $(20)$, our review uncovered the marginalization of MDWs in health and social care system of host countries with service gaps in improving their accessibility to health services, mitigating social isolation, strengthening health literacy, assessing physical and mental health status, and providing health and social care supporting the wellbeing of MDWs. 
Despite such marginalization, there is a clear need to listen to the voice of MDWs (73). This review identified a number of qualitative studies which successfully uncovered the health experiences of MDWs through their narratives. However, small sample size and non-probability sampling was common in quantitative studies, highlighting a research gap in current literature to produce more rigorous design to ensure better generalization. Several mixed methods research studies included in this review were designed to capture experiential aspects of the health-related consequences of working as a MDW. We further advocate for a participatory action research approach to actively empower MDWs through coconstruction of research programmes for social changes. Bhuyan and colleagues (74) demonstrated an excellent example of advocacy for migration policy changes for MDWs in Canada, using a participatory action research approach. The changes were deemed to be important to ameliorate the structural violence of migrant labor (74). According to our findings, we believe that certain areas of research into MDWs should be prioritized, including areas such as health literacy, abuses and mental health of MDWs. Further international research is required to gain greater understandings of the contextualized health needs of MDWs around the world.

There are limitations in this scoping review. Firstly, the inductive nature of scoping review with the diversity of countries included in this review risks the potential for lack of specificity. Secondly, scoping reviews are designed to map the evidence and generally do not exclude studies on the ground of quality appraisal, hence cautions should be paid when interpreting findings from studies with poor quality. Thirdly, this review only included English language literature as a result of screening on English, Chinese and Indonesian papers. Studies in other language (e.g. Filipino) might provide a more contextualized findings for the readers. Fourth, the COVID-19 pandemic may have exacerbated employment constraints and had a negative effect on MDWs' experiences. For example, increased reports of abuse and exploitation have been linked to stay-at-home employers and job security of MDWs was affected by the pandemic (66). However, this review was unable to provide information on COVID-19 pandemic.

\section{Conclusions}

This scoping review has highlighted a multitude of health-related problems in MDWs across three broad areas, namely stressors to health, physical and mental health problems, and coping strategies. It uncovers the lack of formal health and social care support for MDWs in various host countries. Our findings presented an urgent need to design policy and health promotion programmes to mitigate the marginalization of MDWs.

\section{References}


1. Hochschild AR. Global care chains and emotional surplus value. In Giddens A, Hutton W. On the edge: Liviing with global capitalism. London: Jonathan Cape; 2000: 130-146.

2. Basnyat I, Chang L. Examining live-in foreign domestic helpers as a coping resources for family caregivers of people with dementia in Singapore. Health Communication. 2017; 32(9): 11711179 .

3. Ho KHM, Smith GD. A discusive paper on the importance of health literacy among foreign domestic workers during outbreaks of communicable diseases. Journal of Clinical Nursing. 2020; 29(23-24): 4827-4833.

4. Lutz H. At your service madam! The globalizatoin of domestic service. Feminist Review. 2002: p. 89-104.

5. International Labour Organization. Migrant domestic workers. [Online].; 2020 [cited 2020 November 3. Available from: https://www.ilo.org/global/topics/care-economy/migrantdomestic-workers/lang--en/index.htm.

6. Gallotti M. Migrant domestic workers across the world: global and regional estimates. Geneva; 2015.

7. Gavanas A. Elderly care puzzles in Stockholm: Strategies on formal and informal markets. Nordic Journal of Migration Research. 2013; 3(2): 63-71.

8. Palenga-Möllenbeck E. New maids - new butlers? Polish domestic workers in Germany and commodification of social reproductive work. Equality, Diversity and Inclusion: An International Journal. 2013; 32(6): 557-574.

9. Ho KHM, Chiang VCL, Leung D, Ku BHB. When foreign domestic helpers care for and about older people in their homes: I am a maid or a friend. Global Qualitative Nursing Research. 2018; 5: 1-10.

10. Anderson B. Doing the dirty work? The global politics of domestic labour London; New York: Zed Books; 2000.

11. Turnpenny A, Hussein S. Migrant home care workers in the UK: a scoping review of outcomes and sustainability and implications in the context of Brexit. Journal of International Migration and Integration. 2021.

12. Panayiotopoulos P. The globalization of care: Filipina domestic workers and care for the elderly in Cyprus. Capital \& Class. 2005; 86(Summer): 99-133.

13. Tung C. The cost of caring: The social reproductive labour of Filipina live-in home health caregivers. A Journal of Women Studies. 2000; 21(1/2): 61-82.

14. Ayalon L, Shiovitz-Ezra S, Palgi Y. No place like home? Potential pathways to loneliness in older adults under the care of a live-in foreign home care worker. The Journal of Psychology. 2012; 146(1-2): 189-200.

15. Mission for Migrant Workers. Migrants and elderly care: Investigating the conditions, concerns, and needs of migrant domestic workers who are involved in elderly care and assistance. Hong Kong; 2018.

16. National Population and Talent Division. Projection of foreign manpower demand for healthcare sector, construction workers and foreign domestic workers; 2012.

17. Chou YC, Kröger T, Pu CY. Models of long-term care use among older people with disabilities in Taiwan: institutional care, community care, live-in migrant care and family care. European Journal of Ageing. 2015; 12: 95-104. 
18. Ayalon L, Roziner I. Satisfaction with the relationship from the perspective of family caregivers, older adults and their home care workers. Aging \& Mental Health. 2016; 20(1): 56-64.

19. Bourgeault IL, Atanackovic J, Rashid A, Parpia R. Relations between immigrant care workers and older persons in home and long-term care. Canadian Journal on Aging. 2010; 29(1): 109118.

20. Walsh K, Shutes I. Care relationship, quality of care and migrant workers caring for older people. Ageing \& Society. 2013; 33: 393-420.

21. Armstrong P, Armstrong H, Scott-Dixon K. Critical to care: the invisible women in health services. Toronto, Ontario: University of Toronto Press; 2008.

22. Ho KHM, Chiang VCL, Leung D, Cheung DSK. A feminist phenomenology on the emotional labor and morality of live-in migrant care workers caring for older people in the community. BMC Geriatrics. 2019; 19(314): 1-8.

23. Chung RYN, Mak JKL. Physical and mental health of live-in female migrant domestic workers: A randomly sampled survey in Hong Kong. American Behavioral Scientist. 2020: 1-21.

24. Wang J, Wu B. Domestic helpers as frontline workers in China's home-based elder care: A systematic review. Journal of Women \& Aging. 2017; 29(4): 294-305.

25. Lau PW, Cheng JG, Chow DL, Ungvari GS, Leung CM. Acute psychiatric disorder in foreign domestic workers in Hong Kong: a pilot study. International Journal of Social Psychiatry. 2009; 14(3): 569-576.

26. Torriente A. Global action programme on migrant domestic worker and their families: Migrant domestic workers, health and HIV. Geneva; 2016.

27. Gruskin S. What are health and human rights? The Lancet. 2004; 363(9405): 329.

28. Gruskin S, Mills EJ, Tarantola D. History, principles, and practice of health and human rights. The Lancet. 2007: 449-455.

29. Cheung JTK, Tsoi VWY, Wong KHK, Chung RY. Abuse and depression among Filipino foreign domestic helpers. A cross-sectional survey in Hong Kong. Public Health. 2019: 21-127.

30. Alzheimer's Disease International. World Alzheimer report 2015. The global impact of dementia: An analysis of prevalence, incidence, cost and trends. Londoen; 2015.

31. McCabe M, You E, Tatangelo G. Hearing their voice: A systematic review of dementia family caregivers' needs. The Gerontologist. 2016; 56(5): e70-e88.

32. Mosher CE, Bakas T, Champion VL. Physical health, mental health, and life changes among family caregivers of patients with lung cancer. Oncology Nursing Forum. 2013; 40(1): 53-61.

33. Arksey H, O'Malley L. Scoping studies: towards a methodological framework. International Journal of Social Research Methodology. 2005; 8(1): 19-32.

34. Levac D, Colquhoun H, O'Brien KK. Scoping studies: Advancing the methodology. Implementation Science. 2010; 5(1): 69.

35. Cooper S, Cant R, Kelly M, Levett-Jones T, McKenna L, Seaton P, et al. An evidence-based checklist for improving scoping review quality. Clinical Nursing Research. 2021: 230-240.

36. Page MJ, McKenzie JE, Bossuyt PM, Boutron I, Hoffmann TC, Mulrow CD, et al. The PRISMA 2020 statement: an updated guideline for reporting systematic reviews. BMJ. 2021; 372(n71): 
1-10.

37. Covidence. Better systematic review management. [Online]. Available from: https://www.covidence.org.

38. Vaismoradi M, Jones J, Turunen H, Snelgrove S. Theme development in qualitaitve content analysis and thematic analysis. Journal of Nursing Education and Practice. 2016: 100-110.

39. Green O, Ayalon L. Whom do migrant home care workers contact in the case of work-related abuse? An exploratory study of help-seeking behaviors. Journal of Interpersonal Violence. 2016; 31(19): 3236-3256.

40. Green $\mathrm{O}$, Ayalon A. Violations of workers' rights and exposure to work-related abuse of live-in migrant and live-out local home care workers - a preliminary study: implications for health policy and practice. Israel Journal of Health Policy Research. 2018; 7(32): 1-13.

41. Simkhada P, van Teijlingen E, Gurung M, Wasti SP. A survey of health problems of Nepalese female migrant workers in the Middle-East and Malaysia. BMC International Health and Human Rights. 2018; 18(4): 1-7.

42. Toyota M. Health concerns of 'invisible' cross-border domestic maids in Thailand. Asian Population Studies. 2006; 2(1): 19-36.

43. Hill N, Dorow S, Barneston B, Martinez JF, Matsunaga-Turnbull J. Occupatoinal health and safety for migrant domestic workers in Canada: Dimensions of (im)mobility. NEW SOLUTIONS: A Journal of Environmental and Occupational Health Policy. 2019; 29(3): 397-421.

44. Vahabi M, Wong JPH. Caught between a rock and a hard place: mental health of migrant live-in caregivers in Canada. BMC Public Health. 2017; 17(498): 1-15.

45. Kantaris M, Theodorou M, Galanis P, Kaitelidou D. Access and utilization of health services by domestic helpers in Cyprus. The International Journal of Health Planning and Management. 2014; 29(4): e383-e393.

46. Carlos JK, Wilson K. Migrating among temporary foreign workers: examining health and access to health care among Filipina live-in caregivers. Social Science \& Medicine. 2018; 209: 117-124.

47. Fernandez B. Health inequities faced by Ethiopian migrant domestic workers in Lebanon. Health \& Place. 2018; 50: 154-161.

48. Van Bortel T, Martin S, Anjara S, Nellums LB. Perceived stressors and coping mechanisms of female migrant domestic workers in Singapore. PLoS ONE. 2019: e0210717.

49. van der Ham AJ, ujano-Batangan MT, Ignacio R, Wolffers I. The dynamics of migration-related stress and coping of female domestic workers from the Philippines: an exploratory study. Community Mental Health Journal. 2015; 51: 14-20.

50. Zahreddine N, Hady RT, Chammai R, Kazour F, Hachem D, Richa S. Psychiatric morbidity, phenomenology and management in hospitalized female foreign domestic workers in Lebanon. Community Mental Health Journal. 2014: 619-628.

51. Heng JL, Fan E, Chan EY. Caregiving experiences, coping strategies and needs of foreign domestic workers caring for older people. Journal of Clinical Nursing. 2019; 28: 458-468.

52. Ahonen EQ, Lopez-Jacob MJ, Vazquez ML, Porthe V, Gil-Gonzalez D, Garcia AM, et al. Invisible work, unseen hazards: the health of women immigrant household service workers in Spain. Amercian Journal of Industrial Medicine. 2010; 53: 405-416.

53. Anbesse B, Hanlon C, Alem A, Packer S, Whitley R. Migration and mental health: A study of low- 
income Ethiopian women working in middle eastern countries. International Jouranl of Social Psychiatry. 2009; 55(6): 557-568.

54. Anjara SG, Nellums LB, Bonetto C, Van Bortel T. Stress, health and quality of life of female migrant domestic workers in Singapore: a cross-sectional study. BMC Women's Health. 2017; 17(98): 1-13.

55. Hall BJ, Garabiles MR, Latkin CA. Work life, relationship, and policy determinants of health and well-being among Filipino domestic wokers in China: a qualitaitve study. BMC Public Health. 2019; 19(229): 1-14.

56. Mendoza NB, Mordeno IG, Latkin CA, Hall BJ. Evidence of the paradoxical effect of social network support: a study among Filipino domestic workers in China. Psychiatric Research. 2017; 255: 263-271.

57. Gao X, Chan CW, Mak SL, Ng Z, Kwong WH, Kot CCS. Oral health of foreign domestic workers: exploring the social determinants. Journal of Immigrant and Minority Health. 2014: 926-933.

58. Bagley C, Madrid S, Bolitho F. Stress factors and mental health adjustment of Filipino domestic workers in Hong Kong. International Social Work. 1995; 40: 373-382.

59. Lo SF, Chang LJ, Hayter M, O Yang AC. An exploration of factors related to quality of life in Indonesian care workers in home-based care settings. Journal of Nursing Research. 2019: e47.

60. Hall BJ, Pangan CAC, Chan EWW, Huang RL. The effect of discrimination on depression and anxiety symptoms and the buffering role of social capital among female domestic workers in Macao, China. Pyschiatry Research. 2019; 271: 200-207.

61. Garabiles MR, Lao CK, Xiong Y, Hall BJ. Exploring comorbidity between anxiety and depression among migrant Filipino domestic workers: A network approach. Journal of Affective Disorders. 2019; 250: 85-93.

62. Yi G, Huang L, Lam AlF, Latkin C, Hall BJ. Spatial and sociodemographic correlates of gambling participation and disorder among female Filipino migrant workers in Macao, People's Republic of China. Addictive Behaviors. 2019; 97: 49-55.

63. van der Ham AJ, ujano-Batangan MT, Ignacio R, Wolffers I. Toward healthy migration: An exploratory study on the resilience of migrant domestic workers from the Philippines. Transcultural Psychiatry. 2014; 51(4): 545-568.

64. Adelman RD, Tmanova LL, Delgado D, Dion S, Lachs MS. Caregiver burden: a clinical review. JAMA. 2014: 1052-60.

65. Rivera-Navarro J, Del Rey A, Paniagua T. The dark side of the work of immigrant women caregivers in Spain: Qualitative interview findings. Nursing Open. 2019: 1464-1470.

66. Lai Y, Fong E. Work related aggression in home-based working environment: Experiences of migrant domestic workers in Hong Kong. American Behavioral Scientist. 2020: 722-739.

67. Kantaris $\mathrm{M}$, Theodorou $\mathrm{M}$, Kaitelidou $\mathrm{D}$. Access and utilization of health services by migrant domestic helpers in Cyprus: the role of the employer. International Journal of Migration, Health and Social Care. 2019: 46-60.

68. Bauer G, Österle A. Migrant care labour: The commodification and redistribution of care and emotional work. Social Policy and Society. 2013; 12(3): 461-473.

69. Weng S, Malik A, Wongsin U, Lohmeyer F, Lin L, Atique S, et al. Health service access among indonesian migrant domestic workers in Taiwan. International Journal of Environmental Research and Public Health. 2021; 18: 3759. 
70. Yi H. Migrants and health in Hong Kong and its neighbouring countries: putting it in the context of global health Justice and Ethnics. In WUN Conference Migration; 2015; Hong Kong: The Chinese University of Hong Kong: 25-30.

71. Liu W. The embodied crises of neoliberal globalization: the lives and narratives of Filipina migrant domestic workers. Women Studies International Forum. 2015: 80-88.

72. World Health Organization. World Health Organizatoin Regional Office for Europe. [Online].; 2018. Available from: https://www.euro.who.int/en/publications/abstracts/health-2020-priorityarea-four-creating-supportive-environments-and-resilient-communities.-a-compendium-ofinspirational-examples-2018.

73. Dutta MJ, Comer S, Teo D, P LPL, Lee M, Zapata D, et al. Health meanings among foreign domestic workers in Singapore: a culture-centred approach. Health Communication. 2018: 643652.

74. Bhuyan R, Valmadrid L, Panlaqui EL, Pendon NL, Juan P. Responding to the structural violence of migrant domestic work: insights from participatory action reserach with migrant caregivcers in Canada. Journal of Family Violence. 2018: 613-627.

\section{Tables}

Table 1 Characteristics of included literature 


\begin{tabular}{|c|c|c|c|c|c|}
\hline Authors & $\begin{array}{l}\text { Qualitative } \\
\text { / } \\
\text { Qualitative } \\
\text { / mixed } \\
\text { methods }\end{array}$ & $\begin{array}{l}\text { Research } \\
\text { objectives }\end{array}$ & $\begin{array}{l}\text { No. of } \\
\text { sample / } \\
\text { participants }\end{array}$ & $\begin{array}{l}\text { Study } \\
\text { conducting } \\
\text { countries }\end{array}$ & $\begin{array}{l}\text { Origin } \\
\text { countries of } \\
\text { MDWs }\end{array}$ \\
\hline $\begin{array}{l}\text { Ahonen EQ, } \\
\text { Lopez-Jacob } \\
\text { MJ, Vazquez } \\
\text { ML, Porthe } \\
\text { V, Gil- } \\
\text { Gonzalez D, } \\
\text { Garcia AM, } \\
\text { et al., } 2010\end{array}$ & Qualitative & $\begin{array}{l}\text { To examine the } \\
\text { environmental, } \\
\text { ergonomic and } \\
\text { psychosocial } \\
\text { hazards and health } \\
\text { effects identified } \\
\text { by immigrant } \\
\text { women working in } \\
\text { household service } \\
\text { in five Spanish } \\
\text { cities. }\end{array}$ & $\begin{array}{l}46 \text { immigrant } \\
\text { women in } \\
\text { household } \\
\text { services }\end{array}$ & Spain & $\begin{array}{l}\text { Colombia, } \\
\text { Morocco, } \\
\text { Senegal, } \\
\text { Romania, } \\
\text { Equador }\end{array}$ \\
\hline $\begin{array}{l}\text { Anbesse, } \\
\text { Hanlon, } \\
\text { Alem, } \\
\text { Packer, \& } \\
\text { Whitley, } \\
2009\end{array}$ & Qualitative & $\begin{array}{l}\text { To explore } \\
\text { experiences of } \\
\text { female Ethiopian } \\
\text { domestic workers } \\
\text { employed in Middle } \\
\text { Eastern countries } \\
\text { and illuminate } \\
\text { potential threats to } \\
\text { mental health }\end{array}$ & $\begin{array}{l}19 \text { female } \\
\text { domestic } \\
\text { workers (two } \\
\text { groups with } \\
\text { severe } \\
\text { mental } \\
\text { illness and } \\
\text { one mentally } \\
\text { well group) }\end{array}$ & $\begin{array}{l}\text { Middle } \\
\text { East } \\
\text { (Lebanon, } \\
\text { Saudi } \\
\text { Arabia, } \\
\text { Abu Dhabi, } \\
\text { Yemen) }\end{array}$ & Ethiopia \\
\hline $\begin{array}{l}\text { Anjara, } \\
\text { Nellums, } \\
\text { Bonetto, \& } \\
\text { Van Bortel, } \\
2017\end{array}$ & Quantitative & $\begin{array}{l}\text { To investigate } \\
\text { factors impacting } \\
\text { on female domestic } \\
\text { workers' health } \\
\text { and quality of life }\end{array}$ & $\begin{array}{l}182 \text { female } \\
\text { migrant } \\
\text { domestic } \\
\text { workers }\end{array}$ & Singapore & $\begin{array}{l}\text { Philippines, } \\
\text { Indonesia, } \\
\text { Myanmar/Sri } \\
\text { Lanka }\end{array}$ \\
\hline $\begin{array}{l}\text { Bagley, } \\
\text { Madrid, \& } \\
\text { Bolitho, } \\
1995\end{array}$ & Quantative & $\begin{array}{l}\text { To investigate } \\
\text { stress factors, } \\
\text { satisfaction and } \\
\text { mental health } \\
\text { adjustment of } \\
\text { female domestic } \\
\text { helpers }\end{array}$ & $\begin{array}{l}600 \text { female } \\
\text { domestic } \\
\text { helpers }\end{array}$ & Hong Kong & Philippines \\
\hline $\begin{array}{l}\text { Carlos \& } \\
\text { Wilson, } 2018\end{array}$ & Qualitative & $\begin{array}{l}\text { To examine } \\
\text { perceived changes } \\
\text { in health and } \\
\text { barriers to } \\
\text { accessing } \\
\text { healthcare services }\end{array}$ & $\begin{array}{l}21 \text { temporary } \\
\text { female live-in } \\
\text { caregivers }\end{array}$ & Canada & Philippines \\
\hline $\begin{array}{l}\text { Cheung, } \\
\text { Tsoi, Wong, } \\
\text { \& Chung, } \\
2019\end{array}$ & Quantitative & $\begin{array}{l}\text { To explore } \\
\text { experience of } \\
\text { physical and verbal } \\
\text { abuse and } \\
\text { reporting } \\
\text { behaviors; and } \\
\text { associations }\end{array}$ & $\begin{array}{l}105 \text { female } \\
\text { foreign } \\
\text { domestic } \\
\text { helpers }\end{array}$ & Hong Kong & Philippines \\
\hline
\end{tabular}




\begin{tabular}{|c|c|c|c|c|c|}
\hline & & $\begin{array}{l}\text { between abuse } \\
\text { experience and } \\
\text { depression-level }\end{array}$ & & & \\
\hline $\begin{array}{l}\text { Fernandez, } \\
2018\end{array}$ & Qualitative & $\begin{array}{l}\text { To investigate } \\
\text { healthcare needs, } \\
\text { access to } \\
\text { healthcare and } \\
\text { healthcare } \\
\text { strategies of } \\
\text { migrant domestic } \\
\text { workers }\end{array}$ & $\begin{array}{l}55 \text { female } \\
\text { domestic } \\
\text { workers and } \\
17 \text { key } \\
\text { informants }\end{array}$ & Lebanon & Ethiopia \\
\hline $\begin{array}{l}\text { Gao, et al., } \\
2014\end{array}$ & Quantitative & $\begin{array}{l}\text { To explore the } \\
\text { social determinants } \\
\text { of oral health of } \\
\text { foreign domestic } \\
\text { workers }\end{array}$ & $\begin{array}{l}122 \text { female } \\
\text { domestic } \\
\text { helpers }\end{array}$ & Hong Kong & Indonesia \\
\hline $\begin{array}{l}\text { Garabiles, } \\
\text { Lao, Xiong, } \\
\text { \& Hall, } 2019\end{array}$ & Quantitative & $\begin{array}{l}\text { To explore } \\
\text { comorbidity } \\
\text { between anxiety } \\
\text { and depression } \\
\text { among migrant } \\
\text { domestic workers }\end{array}$ & $\begin{array}{l}355 \text { female } \\
\text { domestic } \\
\text { workers }\end{array}$ & $\begin{array}{l}\text { Macao, } \\
\text { China }\end{array}$ & Philippines \\
\hline $\begin{array}{l}\text { Green \& } \\
\text { Ayalon, } 2016\end{array}$ & Quantitative & $\begin{array}{l}\text { To explore the } \\
\text { help-seeking } \\
\text { behavior of migrant } \\
\text { home care workers } \\
\text { exposed to work- } \\
\text { place abuse }\end{array}$ & $\begin{array}{l}85 \text { home care } \\
\text { workers } \\
\text { (86\% female) }\end{array}$ & Israel & Philippines \\
\hline $\begin{array}{l}\text { Green \& } \\
\text { Ayalon, } 2018\end{array}$ & Quantitative & $\begin{array}{l}\text { To assess the } \\
\text { working conditions } \\
\text { and prevalence of } \\
\text { abuse and } \\
\text { exploitation of live- } \\
\text { in and live-out } \\
\text { migrant home care } \\
\text { workers }\end{array}$ & $\begin{array}{l}338 \text { migrant } \\
\text { live-in home } \\
\text { care workers } \\
\text { ( } 84 \% \text { female) } \\
\text { and } 185 \text { local } \\
\text { live-out } \\
\text { workers } \\
\text { (92\% female) }\end{array}$ & Israel & $\begin{array}{l}\text { Russia (live- } \\
\text { out workers) } \\
\text { Not stated } \\
\text { for live-in } \\
\text { workers }\end{array}$ \\
\hline $\begin{array}{l}\text { Hall, } \\
\text { Garabiles, \& } \\
\text { Latkin, } 2019\end{array}$ & Qualitative & $\begin{array}{l}\text { To identify key } \\
\text { health issues faced } \\
\text { by migrant } \\
\text { domestic workers } \\
\text { and the social } \\
\text { determinants }\end{array}$ & $\begin{array}{l}22 \text { female } \\
\text { domestic } \\
\text { workers; } 7 \\
\text { key } \\
\text { informants }\end{array}$ & China & Philippines \\
\hline $\begin{array}{l}\text { Hall, } \\
\text { Pangan, } \\
\text { Chan, \& } \\
\text { Huang, } 2019\end{array}$ & Quantitative & $\begin{array}{l}\text { To investigate the } \\
\text { relationship } \\
\text { between } \\
\text { discrimination and } \\
\text { anxiety and } \\
\text { depressive } \\
\text { symptoms, and }\end{array}$ & $\begin{array}{l}131 \text { female } \\
\text { domestic } \\
\text { workers }\end{array}$ & $\begin{array}{l}\text { Macao, } \\
\text { China }\end{array}$ & Philippines \\
\hline
\end{tabular}




\begin{tabular}{|c|c|c|c|c|c|}
\hline & & $\begin{array}{l}\text { social capital as a } \\
\text { moderator }\end{array}$ & & & \\
\hline $\begin{array}{l}\text { Heng, Fan, } \\
\text { \& Chan, } \\
2019\end{array}$ & Qualitative & $\begin{array}{l}\text { To explore } \\
\text { caregiving } \\
\text { experiences and } \\
\text { coping strategies of } \\
\text { female domestic } \\
\text { workers caring for } \\
\text { older people in } \\
\text { Singapore }\end{array}$ & $\begin{array}{l}11 \text { female } \\
\text { domestic } \\
\text { workers }\end{array}$ & Singapore & $\begin{array}{l}\text { Indonesia, } \\
\text { Philippines, } \\
\text { and Burma }\end{array}$ \\
\hline $\begin{array}{l}\text { Hill, Dorow, } \\
\text { Barneston, } \\
\text { Martinez, \& } \\
\text { Matsunaga- } \\
\text { Turnbull, } \\
2019\end{array}$ & $\begin{array}{l}\text { Mixed } \\
\text { methods }\end{array}$ & $\begin{array}{l}\text { To examine the } \\
\text { occupational health } \\
\text { and safety } \\
\text { experience of } \\
\text { migrant live-in } \\
\text { carers }\end{array}$ & $\begin{array}{l}112 \text { female } \\
\text { domestic } \\
\text { workers ( } 8 \\
\text { interviewed) }\end{array}$ & Canada & Philippines \\
\hline $\begin{array}{l}\text { Kantaris, } \\
\text { Theodorou, } \\
\text { Galanis, \& } \\
\text { Kaitelidou, } \\
2014\end{array}$ & Quantitative & $\begin{array}{l}\text { To investigate the } \\
\text { conditions of } \\
\text { access and } \\
\text { utilization of health } \\
\text { services by } \\
\text { domestic helpers }\end{array}$ & $\begin{array}{l}625 \text { domestic } \\
\text { helpers ( } 98.9 \\
\% \text { female) }\end{array}$ & Cyprus & $\begin{array}{l}\text { Philippines, } \\
\text { Vietnam, Sri } \\
\text { Lank, India } \\
\text { and Other }\end{array}$ \\
\hline $\begin{array}{l}\text { Lo, Chang, } \\
\text { Hayter, \& O } \\
\text { Yang, } 2019\end{array}$ & Quantitative & $\begin{array}{l}\text { To explore stress } \\
\text { levels, social } \\
\text { support } \\
\text { requirements, and } \\
\text { perceived quality of } \\
\text { life among foreign } \\
\text { care } \\
\text { workers in home } \\
\text { care settings }\end{array}$ & $\begin{array}{l}157 \text { foreign } \\
\text { care workers } \\
(99.3 \% \\
\text { female) }\end{array}$ & Taiwan & Indonesia \\
\hline $\begin{array}{l}\text { Mendoza, } \\
\text { Mordeno, } \\
\text { Latkin, \& } \\
\text { Hall, } 2017\end{array}$ & Quantitative & $\begin{array}{l}\text { To examine the role } \\
\text { pf social network } \\
\text { support in } \\
\text { buffering the } \\
\text { impact of } \\
\text { postmigration } \\
\text { stress on mental } \\
\text { health symptoms } \\
\text { among female } \\
\text { domestic workers. }\end{array}$ & $\begin{array}{l}261 \text { female } \\
\text { domestic } \\
\text { workers }\end{array}$ & $\begin{array}{l}\text { Macau, } \\
\text { China }\end{array}$ & Philippines \\
\hline $\begin{array}{l}\text { Simkhada, } \\
\text { van } \\
\text { Teijlingen, } \\
\text { Gurung, \& } \\
\text { Wasti, 2018 }\end{array}$ & Quantitative & $\begin{array}{l}\text { To explore the } \\
\text { health problems of } \\
\text { Nepalese female } \\
\text { migrant workers } \\
\text { working in the } \\
\text { Middle East and } \\
\text { Malaysia }\end{array}$ & $\begin{array}{l}1010 \text { female } \\
\text { migrant } \\
\text { workers }\end{array}$ & $\begin{array}{l}\text { Middle } \\
\text { East, } \\
\text { Kuwait, } \\
\text { Saudia } \\
\text { Arabia, } \\
\text { Malaysia }\end{array}$ & Nepal \\
\hline Toyota, 2006 & Qualitative & To explore the & 3 female & Thailand & Burma \\
\hline
\end{tabular}




\begin{tabular}{|c|c|c|c|c|c|}
\hline & & $\begin{array}{l}\text { health and welfare } \\
\text { concerns of cross- } \\
\text { border domestic } \\
\text { maids in Thailand }\end{array}$ & $\begin{array}{l}\text { domestic } \\
\text { workers }\end{array}$ & & \\
\hline $\begin{array}{l}\text { Vahabi \& } \\
\text { Wong, } 2017\end{array}$ & $\begin{array}{l}\text { Mixed } \\
\text { methods }\end{array}$ & $\begin{array}{l}\text { To explore work- } \\
\text { related experiences } \\
\text { and mental health } \\
\text { of female domestic } \\
\text { workers }\end{array}$ & $\begin{array}{l}30 \text { female } \\
\text { domestic } \\
\text { workers }\end{array}$ & Canada & Philippines \\
\hline $\begin{array}{l}\text { Van Bortel, } \\
\text { Martin, } \\
\text { Anjara, \& } \\
\text { Nellums, } \\
2019\end{array}$ & Qualitative & $\begin{array}{l}\text { To explore the } \\
\text { perceived stressors } \\
\text { and coping } \\
\text { mechanisms of } \\
\text { female migrant } \\
\text { domestic workers }\end{array}$ & $\begin{array}{l}182 \text { female } \\
\text { domestic } \\
\text { workers }\end{array}$ & Singapore & $\begin{array}{l}\text { Philippines, } \\
\text { Indonesia, } \\
\text { Myanmar, } \\
\text { Sri Lanka. }\end{array}$ \\
\hline $\begin{array}{l}\text { van der } \\
\text { Ham, ujano- } \\
\text { Batangan, } \\
\text { Ignacio, \& } \\
\text { Wolffers, } \\
2014\end{array}$ & $\begin{array}{l}\text { Mixed } \\
\text { methods }\end{array}$ & $\begin{array}{l}\text { To explore factors } \\
\text { that contribute to } \\
\text { resilience in female } \\
\text { domestic workers } \\
\text { and the } \\
\text { relationship with } \\
\text { stress and well- } \\
\text { being }\end{array}$ & $\begin{array}{l}500 \text { female } \\
\text { domestic } \\
\text { workers }\end{array}$ & Philippines & Philippines \\
\hline $\begin{array}{l}\text { van der } \\
\text { Ham, ujano- } \\
\text { Batangan, } \\
\text { Ignacio, \& } \\
\text { Wolffers, } \\
2015\end{array}$ & $\begin{array}{l}\text { Mixed } \\
\text { methods }\end{array}$ & $\begin{array}{l}\text { To assess stress } \\
\text { and coping of } \\
\text { female migrant } \\
\text { domestic workers } \\
\text { from the } \\
\text { Philippines in } \\
\text { different phases of } \\
\text { the migration } \\
\text { process }\end{array}$ & $\begin{array}{l}500 \text { female } \\
\text { domestic } \\
\text { workers }\end{array}$ & Philippines & Philippines \\
\hline $\begin{array}{l}\text { Yi, Huang, } \\
\text { Lam, Latkin, } \\
\& \text { Hall, } 2019\end{array}$ & Quantitative & $\begin{array}{l}\text { To investigate the } \\
\text { prevalence of } \\
\text { gambling disorders } \\
\text { in Filipino female } \\
\text { domestic workers } \\
\text { in Macao }\end{array}$ & $\begin{array}{l}1,194 \text { female } \\
\text { domestic } \\
\text { workers }\end{array}$ & $\begin{array}{l}\text { Macao, } \\
\text { China }\end{array}$ & Philippines \\
\hline $\begin{array}{l}\text { Zahreddine, } \\
\text { et al., } 2014\end{array}$ & $\begin{array}{l}\text { Mixed } \\
\text { methods }\end{array}$ & $\begin{array}{l}\text { To assess } \\
\text { psychiatric } \\
\text { morbidity of female } \\
\text { domestic workers }\end{array}$ & $\begin{array}{l}3 \text { female } \\
\text { domestic } \\
\text { workers and } \\
14 \text { Lebanese } \\
\text { females } \\
\text { (control) }\end{array}$ & Lebanon & $\begin{array}{l}\text { Ethiopia, } \\
\text { Bangladesh } \\
\text { and } \\
\text { Philippines }\end{array}$ \\
\hline
\end{tabular}

Table 2 Data Charting on Stressors, Health Problems and Coping Strategies 


\begin{tabular}{|c|c|c|c|}
\hline Authors & Stressors & Health Problems & Coping strategies \\
\hline $\begin{array}{l}\text { Ahonen EQ, } \\
\text { Lopez-Jacob } \\
\text { MJ, Vazquez } \\
\text { ML, Porthe } \\
\text { V, Gil- } \\
\text { Gonzalez D, } \\
\text { Garcia AM, } \\
\text { et al., } 2010\end{array}$ & $\begin{array}{l}\text { Work environment: } \\
\text { Demanding work and } \\
\text { emotional toll from } \\
\text { caring for older adults } \\
\text { Social isolation: Long } \\
\text { working hours and lack } \\
\text { of interaction with co- } \\
\text { workers contributes to } \\
\text { social isolation. } \\
\text { Separation from family } \\
\text { reinforces sense of } \\
\text { otherness in host country }\end{array}$ & $\begin{array}{l}\text { Physical health: poor } \\
\text { sleep and fatigue } \\
\text { related to mental } \\
\text { issues } \\
\text { Mental health: anxiety } \\
\text { and depression }\end{array}$ & NA \\
\hline $\begin{array}{l}\text { Anbesse, } \\
\text { Hanlon, } \\
\text { Alem, } \\
\text { Packer, \& } \\
\text { Whitley, } \\
2009\end{array}$ & $\begin{array}{l}\text { Financial hardship: MDW } \\
\text { must endure demanding } \\
\text { work conditions as } \\
\text { unable to quit domestic } \\
\text { work due to financial } \\
\text { hardship } \\
\text { Social isolation: Major } \\
\text { stressor }\end{array}$ & $\begin{array}{l}\text { Progressive health } \\
\text { declines post- } \\
\text { migration } \\
\text { Mental } \\
\text { health: loneliness and } \\
\text { homesickness }\end{array}$ & $\begin{array}{l}\text { Social } \\
\text { support: Establishing } \\
\text { social networks and } \\
\text { contact with fellow } \\
\text { workers and engaging in } \\
\text { religious worship } \\
\text { together, though social } \\
\text { contacts may be } \\
\text { prohibited by employers }\end{array}$ \\
\hline $\begin{array}{l}\text { Anjara, } \\
\text { Nellums, } \\
\text { Bonetto, \& } \\
\text { Van Bortel, } \\
2017\end{array}$ & $\begin{array}{l}\text { Social isolation: Major } \\
\text { stressor }\end{array}$ & Mental health: stress & $\begin{array}{l}\text { Social support: higher } \\
\text { quality of life for more } \\
\text { socially connected MDWs }\end{array}$ \\
\hline $\begin{array}{l}\text { Bagley, } \\
\text { Madrid, \& } \\
\text { Bolitho, } \\
1995\end{array}$ & NA & $\begin{array}{l}\text { Mental health: stress; } \\
\text { anxiety and moderate } \\
\text { to severe depression }\end{array}$ & NA \\
\hline $\begin{array}{l}\text { Carlos \& } \\
\text { Wilson, } \\
2018\end{array}$ & $\begin{array}{l}\text { Access to health } \\
\text { services: Lack of health } \\
\text { insurance coverage - low } \\
\text { levels of knowledge of } \\
\text { MDW entitlement to } \\
\text { compulsory health } \\
\text { insurance from } \\
\text { employers } \\
\text { Social } \\
\text { isolation: Separation } \\
\text { from family contributes } \\
\text { to social isolation. }\end{array}$ & $\begin{array}{l}\text { Physical } \\
\text { health: cardiovascular } \\
\text { diseases and poor } \\
\text { sleep post-migration } \\
\text { Mental health: stress, } \\
\text { anxiety and depression }\end{array}$ & NA \\
\hline $\begin{array}{l}\text { Cheung, } \\
\text { Tsoi, Wong, } \\
\text { \& Chung, } \\
2019\end{array}$ & $\begin{array}{l}\text { Work-related abuse: } \\
\text { physical and verbal } \\
\text { abuse }\end{array}$ & $\begin{array}{l}\text { Mental health: } \\
\text { moderate to severe } \\
\text { depression }\end{array}$ & NA \\
\hline
\end{tabular}




\begin{tabular}{|c|c|c|c|}
\hline $\begin{array}{l}\text { Fernandez, } \\
2018\end{array}$ & $\begin{array}{l}\text { Access to health } \\
\text { services: Poor access to } \\
\text { healthcare arising from } \\
\text { structural exclusion from } \\
\text { healthcare system }\end{array}$ & $\begin{array}{l}\text { Physical } \\
\text { health: cardiovascular } \\
\text { and respiratory } \\
\text { diseases and chronic } \\
\text { pain post-migration. } \\
\text { Reproductive health } \\
\text { concerns due to lack of } \\
\text { access to health } \\
\text { services. }\end{array}$ & NA \\
\hline $\begin{array}{l}\text { Gao, et al., } \\
2014\end{array}$ & & $\begin{array}{l}\text { Physical health: poorer } \\
\text { oral health post- } \\
\text { migration linked to } \\
\text { psychosocial } \\
\text { determinants }\end{array}$ & NA \\
\hline $\begin{array}{l}\text { Garabiles, } \\
\text { Lao, Xiong, } \\
\text { \& Hall, } \\
2019\end{array}$ & & $\begin{array}{l}\text { Mental health: } \\
\text { increased anxiety, } \\
\text { depression, } \\
\text { somatization and post- } \\
\text { traumatic stress } \\
\text { disorders associated } \\
\text { with post-migration } \\
\text { stress }\end{array}$ & NA \\
\hline $\begin{array}{l}\text { Green \& } \\
\text { Ayalon, } \\
2016\end{array}$ & $\begin{array}{l}\text { Work-related abuse: } \\
\text { sexual abuse, physical } \\
\text { abuse, emotional abuse, } \\
\text { and exploitation }\end{array}$ & NA & $\begin{array}{l}\text { Social support: Low } \\
\text { reporting rate of abuse to } \\
\text { formal or informal } \\
\text { supports }\end{array}$ \\
\hline $\begin{array}{l}\text { Green \& } \\
\text { Ayalon, } \\
2018\end{array}$ & $\begin{array}{l}\text { Work-related } \\
\text { abuse: migrant domestic } \\
\text { workers more vulnerable } \\
\text { to abuse than local care } \\
\text { workers. } \\
\text { Abuse of workers' rights } \\
\text { (e.g., lack of written } \\
\text { contracts, vacation and } \\
\text { sick leave, financial } \\
\text { compensation and time } \\
\text { off). }\end{array}$ & NA & NA \\
\hline $\begin{array}{l}\text { Hall, } \\
\text { Garabiles, \& } \\
\text { Latkin, } \\
2019\end{array}$ & NA & $\begin{array}{l}\text { Physical } \\
\text { health: cardiovascular } \\
\text { diseases, chronic pain, } \\
\text { diabetes post- } \\
\text { migration } \\
\text { Mental health: anxiety } \\
\text { and depression, } \\
\text { moderate to severe } \\
\text { depression. Mental } \\
\text { health issues coupled } \\
\text { with poor social }\end{array}$ & $\begin{array}{l}\text { Social support: Peer } \\
\text { sharing of same problems } \\
\text { and stresses can have } \\
\text { negative impact on } \\
\text { MDWs }\end{array}$ \\
\hline
\end{tabular}

Page 22/26 


\begin{tabular}{|c|c|c|c|}
\hline & & $\begin{array}{l}\text { support contributed to } \\
\text { addictive gambling }\end{array}$ & \\
\hline $\begin{array}{l}\text { Hall, } \\
\text { Pangan, } \\
\text { Chan, \& } \\
\text { Huang, } \\
2019\end{array}$ & NA & Mental health: anxiety & $\begin{array}{l}\text { Social support: Social } \\
\text { network peer support } \\
\text { associated with } \\
\text { psychological distress }\end{array}$ \\
\hline $\begin{array}{l}\text { Heng, Fan, } \\
\text { \& Chan, } \\
2019\end{array}$ & $\begin{array}{l}\text { Work environment: } \\
\text { Demanding work and } \\
\text { daily hours, particular } \\
\text { when caring for older } \\
\text { adults } \\
\text { Social isolation: Long } \\
\text { working hours and lack } \\
\text { of interaction with co- } \\
\text { workers contributes to } \\
\text { social isolation }\end{array}$ & NA & $\begin{array}{l}\text { Social } \\
\text { support: Employers were } \\
\text { identified as first line } \\
\text { source of support. } \\
\text { Maintaining regular } \\
\text { contact with family } \\
\text { through messages, phone } \\
\text { calls and video calls }\end{array}$ \\
\hline $\begin{array}{l}\text { Hill, Dorow, } \\
\text { Barneston, } \\
\text { Martinez, \& } \\
\text { Matsunaga- } \\
\text { Turnbull, } \\
2019\end{array}$ & $\begin{array}{l}\text { Workplace abuse: } \\
\text { vulnerability of MDW to } \\
\text { abuse and exploitation as } \\
\text { private workplace } \\
\text { presents challenges for } \\
\text { enforcement of labor law } \\
\text { Work environment: } \\
\text { Demanding work and } \\
\text { daily hours }\end{array}$ & $\begin{array}{l}\text { Physical } \\
\text { health: increased } \\
\text { fatigue post-migration } \\
\text { Mental health: stress }\end{array}$ & NA \\
\hline $\begin{array}{l}\text { Kantaris, } \\
\text { Theodorou, } \\
\text { Galanis, \& } \\
\text { Kaitelidou, } \\
2014\end{array}$ & $\begin{array}{l}\text { Access to health } \\
\text { services: Unmet needs } \\
\text { for health services, } \\
\text { pharmaceuticals and low } \\
\text { health literacy }\end{array}$ & NA & $\begin{array}{l}\text { Social } \\
\text { support: Employers were } \\
\text { identified as first line } \\
\text { source of support }\end{array}$ \\
\hline $\begin{array}{l}\text { Lo, Chang, } \\
\text { Hayter, \& O } \\
\text { Yang, } 2019\end{array}$ & NA & Mental health: stress & NA \\
\hline $\begin{array}{l}\text { Mendoza, } \\
\text { Mordeno, } \\
\text { Latkin, \& } \\
\text { Hall, } 2017\end{array}$ & NA & $\begin{array}{l}\text { Mental health: } \\
\text { increased anxiety, } \\
\text { depression, } \\
\text { somatization and post- } \\
\text { traumatic stress } \\
\text { disorders associated } \\
\text { with post-migration } \\
\text { stress }\end{array}$ & $\begin{array}{l}\text { Social support: Peer } \\
\text { sharing of same problems } \\
\text { and stresses can have a } \\
\text { negative impact and } \\
\text { result in psychological } \\
\text { distress }\end{array}$ \\
\hline $\begin{array}{l}\text { Simkhada, } \\
\text { van } \\
\text { Teijlingen, }\end{array}$ & $\begin{array}{l}\text { Workplace } \\
\text { abuse: physical harm, } \\
\text { torture and maltreatment }\end{array}$ & $\begin{array}{l}\text { Physical health: poorer } \\
\text { reproductive and } \\
\text { sexual health post- } \\
\text { migration } \\
\text { Page } 23 / 26\end{array}$ & NA \\
\hline
\end{tabular}




\begin{tabular}{|c|c|c|c|}
\hline $\begin{array}{l}\text { Gurung, \& } \\
\text { Wasti, } 2018\end{array}$ & $\begin{array}{l}\text { Access to health } \\
\text { services: low rates of } \\
\text { MDWs receiving health } \\
\text { services and poor health } \\
\text { literacy associated with } \\
\text { health problems } \\
\text { Work environment: } \\
\text { Demanding work and } \\
\text { daily hours }\end{array}$ & $\begin{array}{l}\text { Mental health: mental } \\
\text { health problems }\end{array}$ & \\
\hline $\begin{array}{l}\text { Toyota, } \\
2006\end{array}$ & $\begin{array}{l}\text { Workplace abuse: Sexual } \\
\text { abuse by male employer } \\
\text { of male worker } \\
\text { Access to health services: } \\
\text { low health literature } \\
\text { (e.g., poor AIDS } \\
\text { knowledge) } \\
\text { Social isolation: Major } \\
\text { stressor. Employers play } \\
\text { major role in } \\
\text { constructing social } \\
\text { isolation. }\end{array}$ & $\begin{array}{l}\text { Physical health: poorer } \\
\text { reproductive and } \\
\text { sexual health post- } \\
\text { migration }\end{array}$ & NA \\
\hline $\begin{array}{l}\text { Vahabi \& } \\
\text { Wong, } 2017\end{array}$ & $\begin{array}{l}\text { Access to health } \\
\text { services: Poor access to } \\
\text { healthcare arising from } \\
\text { structural exclusion from } \\
\text { healthcare system } \\
\text { Financial hardship: MDW } \\
\text { must endure demanding } \\
\text { work conditions as } \\
\text { unable to quit domestic } \\
\text { work due to financial } \\
\text { hardship } \\
\text { Social isolation: Major } \\
\text { stressor }\end{array}$ & $\begin{array}{l}\text { Progressive health } \\
\text { declines post- } \\
\text { migration } \\
\text { Physical } \\
\text { health: diabetes post- } \\
\text { migration } \\
\text { Mental health: anxiety } \\
\text { and depression }\end{array}$ & NA \\
\hline $\begin{array}{l}\text { Van Bortel, } \\
\text { Martin, } \\
\text { Anjara, \& } \\
\text { Nellums, } \\
2019\end{array}$ & $\begin{array}{l}\text { Financial hardship: } \\
\text { Motivation to join } \\
\text { domestic care workforce }\end{array}$ & $\begin{array}{l}\text { Progressive health } \\
\text { declines post- } \\
\text { migration }\end{array}$ & $\begin{array}{l}\text { Social support: Social } \\
\text { support not always } \\
\text { helpful for coping } \\
\text { Religious activity: } \\
\text { participating in religious } \\
\text { activity coping strategy } \\
\text { for stress }\end{array}$ \\
\hline $\begin{array}{l}\text { van der } \\
\text { Ham, ujano- } \\
\text { Batangan, }\end{array}$ & NA & NA & $\begin{array}{l}\text { Religious activity: } \\
\text { praying/reading bible a } \\
\text { coping strategy for stress }\end{array}$ \\
\hline
\end{tabular}




\begin{tabular}{|c|c|c|c|}
\hline $\begin{array}{l}\text { Ignacio, \& } \\
\text { Wolffers, } \\
2014\end{array}$ & & & $\begin{array}{l}\text { (though actual impact not } \\
\text { demonstrated) }\end{array}$ \\
\hline $\begin{array}{l}\text { van der } \\
\text { Ham, ujano- } \\
\text { Batangan, } \\
\text { Ignacio, \& } \\
\text { Wolffers, } \\
2015\end{array}$ & $\begin{array}{l}\text { Financial hardship: } \\
\text { Income and finances } \\
\text { dominant concerns of } \\
\text { MDWs } \\
\text { Work environment: } \\
\text { Demanding work is } \\
\text { detrimental to well-being } \\
\text { and does not provide } \\
\text { secure long-term } \\
\text { solutions to financial } \\
\text { hardship }\end{array}$ & $\begin{array}{l}\text { Mental } \\
\text { health: loneliness and } \\
\text { homesickness }\end{array}$ & $\begin{array}{l}\text { Social } \\
\text { support: Employers were } \\
\text { identified as first line } \\
\text { source of support } \\
\text { Religious activity: } \\
\text { praying/reading bible a } \\
\text { coping strategy for stress }\end{array}$ \\
\hline $\begin{array}{l}\text { Yi, Huang, } \\
\text { Lam, Latkin, } \\
\text { \& Hall, } \\
2019\end{array}$ & NA & $\begin{array}{l}\text { Mental health: Mental } \\
\text { health issues coupled } \\
\text { with poor social } \\
\text { support contributed to } \\
\text { addictive gambling }\end{array}$ & NA \\
\hline $\begin{array}{l}\text { Zahreddine, } \\
\text { et al., } 2014\end{array}$ & $\begin{array}{l}\text { Work environment: } \\
\text { Demanding work and } \\
\text { daily hours }\end{array}$ & $\begin{array}{l}\text { Mental health: } \\
\text { moderate to severe } \\
\text { depression. Two-thirds } \\
\text { of MDWs diagnosed } \\
\text { with brief psychotic } \\
\text { episode. }\end{array}$ & NA \\
\hline
\end{tabular}

\section{Competing Interests}

The authors declare no competing interests.

\section{Figures}




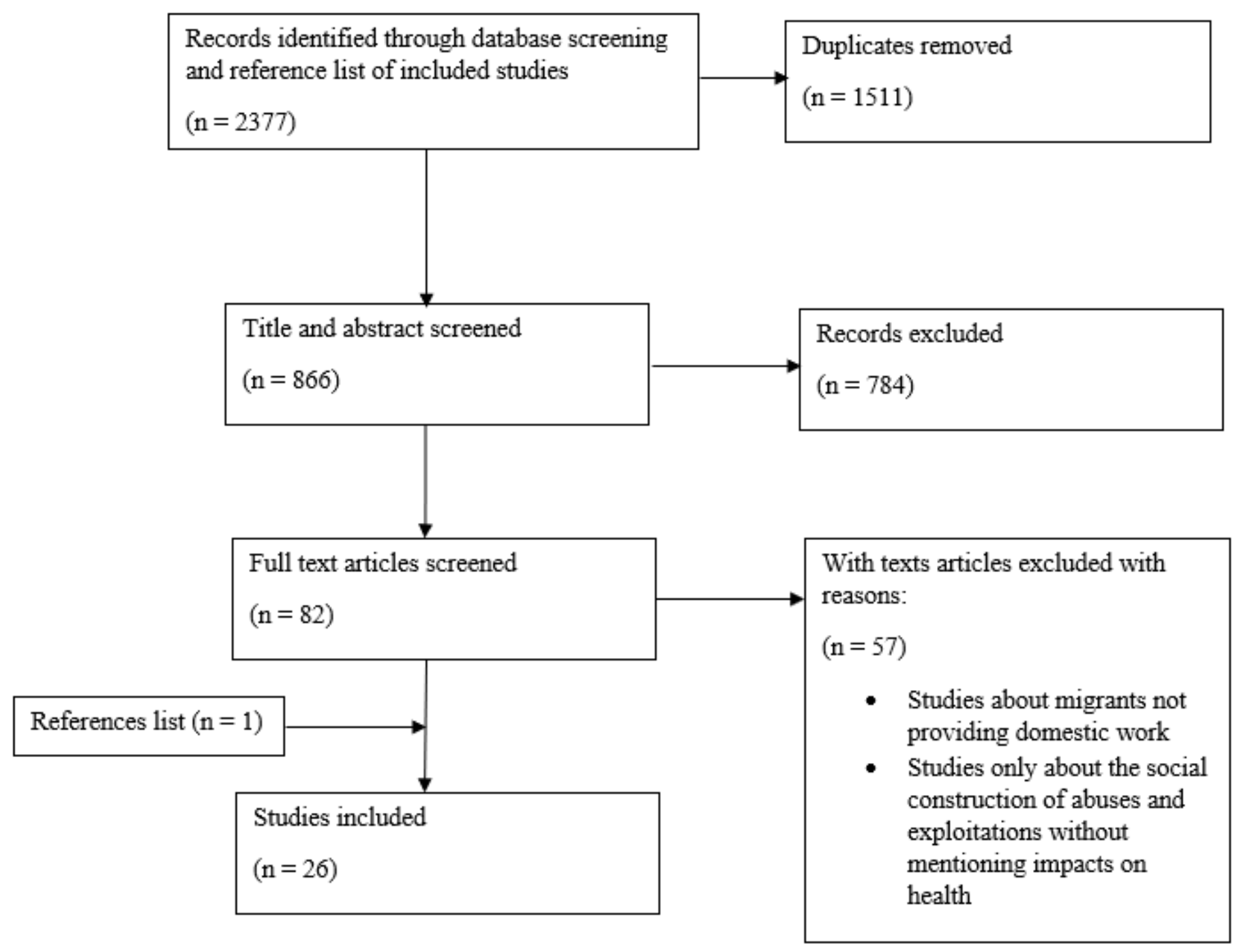

Figure 1

PRISMA Flow chart 